\title{
EML4/ALK Fusion Protein Variant 1
}

National Cancer Institute

\section{Source}

National Cancer Institute. EML4/ALK Fusion Protein Variant 1. NCI Thesaurus. Code C99734.

A fusion protein (1059 aa, 117 kDa) that is encoded by the EML4/ALK variant 1 fusion gene. This protein is comprised of the $\mathrm{N}$-terminal half of the echinoderm microtubuleassociated protein-like 4 fused to the entire cytoplasmic domain of the ALK tyrosine kinase receptor protein including the tyrosine kinase domain. 